Prof. Fersman in the introduction to his book on "The Precious Stones of Russia," " to fly away into the world of the beautiful stone. I want to carry away $m y$ friends and the friends of stones from the heartrending surroundings of their everyday life, into another world, and in a number of talks I have tried to show the riches of Russia in her precious stones."

At the head of this Committee there stands a Council of the most prominent men of science. The president of the Council is a member of the Academy -Prof. V. I. Vernadsky---while another member is N. S. Kournakoff, vice-president. The Committee was founded by the Russian Academy of Science in I9I 5. As Russia during the War was cut off from the world's market, it had to make use of its own resources, and increased knowledge of these natural resources became necessary.

M. Vernadsky expressed this idea in the following words in $1915:$ " We are in such a position as regards a whole number of our natural products, that we even do not know if we have them, and if we have got them, then in what quantities - all this is because we have got used to getting them from abroad and have given up looking for them in our own country.' Russia, therefore, needed a systematic survey of its natural resources in order to become self-supporting. The problem of developing the natural resources has been put forward by the Committee ever since as a great national goal.

The author of the project of founding a special institute for the geographical study of Russia, A. A. Gavriloff, says in May I9I9, "The world's economy must pass through an epoch of highly organised national economies, in which the highest possible organisation of production and useful development of the natural resources of the country reduce to a minimum the competition between the different undertakings within the country. In this way is obtained increased economic strength and means for productive competition with other nations. It is only natural that Russia must needs follow along this path."

The Committee of the Academy of Science has rendered a great service to Russia by collecting and systematising so much material in connexion with the natural resources of Russia. Since I9I5 to I920 it has published 13,469 pages of scientific works. This Committee has likewise rendered a service to world economy; every foreigner who wants to take to Russia his capital or his knowledge for the development of Russia's natural resources will find in these works clear and definite answers to the questions which interest him in connexion with different branches of industry.

Limitations of space forbid a detailed account of the works mentioned above. Special attention may be directed, however, to the brilliant work of Prof. Fersman on the precious stones of Russia, and to works with most detailed and careful information on Russian coal, naphtha, platinum, and gold. Attention may also be directed to the energetic action of the Committee in supporting new industries started in Russia before the War began, such as the production of radium and vanadium from the Tuja-Mujunski mines. Before the War this was undertaken and carried out by the Fergan Society of Rare Metals. With the nationalisation of the mines this young undertaking might otherwise have been killed.

The Committee for the Study of Russia's Natural Resources has formed a special section in connexion with rare metals and radioactive substances. This includes such prominent men of science as Vernadsky and Kournakoff, both of whom are members of the Academy, and Profs. Jakovkin, Joffe, Veber, Sokoloff, Lialin, and Khlopin. What is even more, this section has obtained a Government grant, and has started works in connexion with the production of radium. Information relating to this interesting section of the work of the Committee will be found in the Transactions of the Committee of the Academy of Science for I9I8.

\title{
The Geological History of South-Eastern Australia, with Special Reference to the Carboniferous and Permian Periods. ${ }^{1}$
}

\section{By C. A. Sussmilch.}

ROCKS of definite Archæozoic age occur only over a limited area in the western part of southeastern Australia ; they contain the important silverlead-zinc ore-deposits of the Broken Hill District. Proterozoic strata are limited also to the same area; these contain glacial tillites which have usually in the past been considered Cambrian, but they are probably of pre-Cambrian age. No undoubted Cambrian strata are known to occur in New South Wales.

Ordovician strata are very extensively developed, both in New South Wales and in Victoria : they con sist mainly of claystones with some fine-grained sandstones, and contain an abundant graptolite-fauna. Both Lower and Upper Ordovician strata are found in Victoria, but so far only the latter have been identified in New South Wales. Silurian strata are developed over extensive areas in New South Wales, particularly in the southern and central parts of the State, and extend also through the centre of Victoria; in addition to claystones, there is a considerable development of limestones, individual beds ranging up to 550 feet in thickness. An abundant coralline fauna is preserved in these limestones and there are also many brachiopods and hydrozoa.

1 Substance of a lecture delivered before the Geological Society of London on May $2 \mathrm{I}$.

$$
\text { NO. } 2854 \text {, VOL. I I } 4 \text { ] }
$$

The sea appears to have retreated from the land at the close of the Silurian Period in south-eastern Australia, but renewed transgressions of limited extent took place early in the Devonian Period. The sedimentation which took place in these areas in Lower and Middle Devonian times was accompanied by very extensive deposition of lavas and tuffs, this being one of the important volcanic epochs of south. eastern Australia. Thick coralline limestones were also deposited during that age. Important crustal movements took place at the close of the Middle Devonian times, followed by an extensive transgression of the sea in New South Wales in the Upper Devonian Period, a transgression which extended from the present south-eastern coast almost to the far western boundaries of the State. In the strata deposited in this epicontinental sea an abundant brachiopod fauna is preserved, together with numerous fish-remains. Important crustal movements took place at the end of the Devonian Period, which brought about a complete withdrawal of the sea; much of south-eastern Australia has not since been beneath the sea.

Early in the Carboniferous Period a geosyncline developed in north-eastern New South Wales, and in this was first deposited a series of marine strata in 
the latter part of Lower Carboniferous times. Following a withdrawal of the sea, an extensive series of terrestrial beds was deposited in this area in Middle and Upper Carboniferous times; these terrestrial strata consist mainly of conglomerates, volcanic rocks (lavas and tuffs), and glacial beds, of an aggregate thickness approaching io, ooo feet. The glacial beds are of such a thickness and volume as to imply intense and long-continued glaciation. Associated with these beds is a characteristic Rhacopteris fossil flora.

In Permian (Permo-Carboniferous) time an alternating series of marine and freshwater beds was deposited in the north-eastern part of New South Wales, and these extend far northwards into eastern Queensland. The freshwater beds contain the most productive coalmeasures of Australia, and associated with the coalseams is the characteristic Glossopteris flora. The glacial conditions of the Carboniferous Period continued also far into the Permian Period, but with apparently reduced intensity. The Permian Period closed in north-eastern New South Wales and southeastern Queensland with pronounced orogenic movements, accompanied by granitic intrusions; but elsewhere in New South Wales and throughout Victoria and Tasmania, no earth-folding took place at that time.

In the Trias-Jura Period the whole of eastern
Australia stood above the sea, and extended far east of the present shore-line. Upon this land there developed a number of large lake-basins in which several thousands of feet of freshwater strata were deposited, and in some areas productive coal-measures were formed. In the Cretaceous Period a transgression of the sea began in the north, and extended southwards over central Queensland into northern New South Wales, and well into central Australia. At the beginning of the Tertiary Period a tilting of the Australian continent on an east-and-west axis caused the Cretaceous sea to retreat northwards, and allowed of transgression taking place over considerable areas in the south, incidentally separating Tasmania from the mainland.

The close of the Tertiary Period was marked by a great epeirogenic uplift in eastern Australia, which produced the existing tablelands trending paralle to the eastern coast of Australia. The elevation of these tablelands was accompanied by extensive block-faulting. During the Pleistocene Period, limited high areas in New South Wales and Tasmania supported glaciers and ice-sheets; more recently, a subsidence of the land (or raising of sea-level) drowned the shore-line to an extent of about 200 feet, and still later an upward movement of the strand-line of some Io to 20 feet has taken place.

\section{The Japanese Earthquake of September I, I923.}

SHORTLY after the Japanese earthquake of $S$ September I, 1923, Mr. Takeo Kato, on behalf of the Imperial Earthquake Investigation Committee, made reconnaissances through the districts of violent shocks, especially those around Sagami Bay. He has published a preliminary report on this field study in the Journal of the Geological Society of Tokyo (vol. 30 , No. 36r), including some definite estimates of the loss of life and property. In Tokyo, though not a house escaped some damage, the number of houses that collapsed owing to the shock was comparatively small. The latest official statistics place the number of houses destroyed by fire in Tokyo at 316,087 , the number of killed at 67,052 , of injured at 32,583 , and of missing at 38,980 . The shocks were far stronger at Yokohama, and strongest of all in the districts around Sagami Bay. In six towns along and near the borders of the Bay, 84,300 houses were destroyed and 26,37o lives were lost.

From seismographic and other evidence, the epicentre of the great earthquake seems to lie in Sagami Bay, about midway between Oshima and Hiratsuka, near the mouth of the Sagami River, and probably a little nearer the latter place. In the two months following this shock, the number of aftershocks was more than 1350 ; there were 365 on September I, and 289, I 73, and I43 during the next three days; afterwards the normal decline in frequency was manifested. The epicentres of these after-shocks lay at different places more or less remote from the main one. A few minutes after the great earthquake sea-waves swamped the shores of Sagami Bay, from Shimoda in the Idzu peninsula to Misaki and Uraga in the Miura peninsula, and also along the southern part of the Boso peninsula. They caused much damage only at Ito, Atami, Kamakura, and a few other places, where the height of the waves ranged from 20 to 40 feet. No conspicuous sea-waves were seen in Tokyo Bay. No great fault-scarps or traces have been observed, but in the islet of Hatsushima, off Atami, a fissure was traced for about half a mile, with in some places a displacement of 3 feet or more, running in the direction N. $30^{\circ} \mathrm{W}$. Another, rather more than a mile in length, was found near Nagasawa in the Miura peninsula. Both fissures may be regarded as minor faults of the main fault along which the great earthquake originated.

A remarkable upheaval of the ground took place, it is said, within a few minutes after this earthquake, over an area of about 2000 square miles, including the islet of Hatsu-shima, the headland of Manazuru, the northern border of Sagami Bay, the Miura and Boso peninsulas. The greatest upheaval (about 8 feet) occurred at Tomizaki, along the southern coast of the Boso peninsula, and it is remarkable that here the ground settled down more than a foot within one month after the upheaval. According to the soundings made by the Navy Hydrographic Office, conspicuous changes in depth, of 50 fathoms and more, have occurred at various places in the deepest portion of Sagami Bay. Soundings are still being carried out in the Bay, while many levelling parties of the Military Department are engaged in ascertaining the changes in elevation throughout the earthquake area.

It is worthy of notice that the epicentre lies in the deepest region of Sagami Bay. This trough, which has a N.N.W. direction from Oshima to Hiratsuka, appears to be the southern continuation of the valley of the Sagami River running in the same direction. Moreover, tectonic lines in this direction are numerous, as indicated by the coast borders, valley courses, etc., and the minor faults at Hatsu-shima and Nagasawa run nearly parallel to this direction. The origin of the earthquake is attributed to a great compressive force, probably from the east, which has been accumulating for a long time. The last great earthquake in the district occurred on November 22, I703, and seems to have originated in a great fault along the same tectonic line, the epicentre lying apparently a little to the south of that in 1923. A similar upheaval of land is recorded at that time.

C. D.

NO. 2854 , voL. I I 4 ] 